003I-3998/84/1805-0434\$02.00/0

PEDIATRIC RESEARCH

Copyright (C) 1984 International Pediatric Research Foundation, Inc.

Vol. 18, No. 5, 1984 Prinled in U.S.A.

\title{
Lung Fluid Balance in Hypoxic Lambs
}

\author{
THOMAS N. HANSEN, ${ }^{(48)}$ CHARLES M. HABERKERN, THOMAS A. HAZINSKI, AND \\ RICHARD D. BLAND \\ Cardiovascular Research Institute and Department of Pediatrics, University of California, San Francisco, \\ California; Department of Pediatrics, Baylor College of Medicine, Houston, Texas; and Department of Pediatrics, \\ Northwestern University School of Medicine, Chicago, Illinois, USA
}

\section{Summary}

In spontaneously breathing newborn lambs, alveolar hypoxia increases lung microvascular pressure, which causes lung lymph flow to increase and the concentration of protein in lymph to decrease. To see if this response derives from hypoxia itself rather than from the change in breathing pattern that occurs during hypoxia, we measured lung vascular pressures, pleural pressure, cardiac output, and lung lymph flow in 12 anesthetized lambs that were ventilated at a fixed rate and tidal volume, first with air, then with $10-14 \% \mathrm{O}_{2}$ in nitrogen. Alveolar hypoxia did not affect pleural pressure, but pulmonary arterial pressure increased from 19 to 32 torr, lung lymph flow increased from 2.20 to $3.83 \mathrm{ml} / \mathrm{h}$ and lymph protein concentration decreased from 3.4 to $2.8 \mathrm{~g} / \mathrm{dl}$. To be certain that the increased lymph flow associated with hypoxia is not simply the result of an acute release of fluid from the lungs and to assess the effects of carbon dioxide on lymph flow during hypoxia, we next studied six unanesthetized lambs kept hypoxic for a total of $12 \mathrm{~h}$. After a 2-4-h period in air the lambs breathed 9-11\% $\mathrm{O}_{2}$ in nitrogen for $2-4 \mathrm{~h}$, then 8$11 \% \mathrm{O}_{2}$ and 3-5\% $\mathrm{CO}_{2}$ in nitrogen for 8-10 h. In these lambs we injected intravenously radioactive albumin and measured its uptake in lymph to see if sustained hypoxia alters microvascular permeability to protein in the lungs. In these experiments pulmonary arterial pressure increased from 17 to 37 torr, lung lymph flow increased from 1.74 to $3.28 \mathrm{ml} / \mathrm{h}$, and lymph protein concentration decreased from 3.8 to $3.1 \mathrm{~g} / \mathrm{dl}$ during hypoxia. Addition of $\mathrm{CO}_{2}$ to the inspired gas did not affect steady state lung lymph flow. Lymph flow remained elevated throughout the $12 \mathrm{~h}$ of alveolar hypoxia, and postmortem lung water determinations were not different from those of controls $(4.65 \pm 0.28$ versus 4.72 $\pm 0.14 \mathrm{~g} / \mathrm{g}$ dry bloodless lung). The time required for radioactive albumin to equilibrate in lymph at one-half the specific activity of plasma was no different before and during hypoxia $(130 \pm 7$ versus $125 \pm 11 \mathrm{~min}$ ). We conclude that in the newborn lamb, alveolar hypoxia increases transvascular fluid filtration by increasing microvascular hydraulic pressure without altering microvascular permeability to protein. This response is independent of changes in pleural pressure or inspired carbon dioxide.

Bressack and Bland $(5,6)$ showed that alveolar hypoxia increases lung lymph flow and decreases lymph protein concentration in newborn lambs. They concluded that alveolar hypoxia increases transvascular fluid filtration in the lung by increasing filtration pressure without altering microvascular permeability to protein.

At least two issues were unanswered by the previous studies. First, because Bressack and Bland used unanesthetized lambs that breathed spontaneously, hypoxia caused hyperventilation and a resultant decrease in arterial $\mathrm{PCO}_{2}$ and pleural pressure. Arterial $\mathrm{PCO}_{2}$ may influence pulmonary vascular tone $(20,25)$ and pleural pressure may influence lung interstitial fluid pressure $(14,21,27,38,45)$; it is possible that one or both of these changes could have affected lung fluid balance. Second, the studies done by Bressack and Bland lasted only 4-6 hr, and they could not exclude the possibility that the increased lymph flow may have been transient, caused by release of lung intracellular fluid rather than filtration of fluid from the microcirculation.

To help clarify these points we prepared 18 newborn lambs for study of lung fluid balance under different sets of experimental conditions. We studied 12 anesthetized lambs that were ventilated at a fixed rate and tidal volume, first with air and then with $10-14 \% \quad \mathrm{O}_{2}$ in nitrogen. Lymph flow increased during alveolar hypoxia in all 12 lambs and pleural pressure remained unchanged. Next, we studied six unanesthetized lambs that first breathed air during a 2-4-h control period, then $9-11 \% \mathrm{O}_{2}$ in nitrogen for $2-4 \mathrm{~h}$, and then $8-11 \% \mathrm{O}_{2}$ and $3-5 \% \mathrm{CO}_{2}$ in nitrogen for $8-10 \mathrm{~h}$. The hypoxia-induced increase in lung lymph flow was unaffected by addition of carbon dioxide to the inspired gas. Lymph flow remained elevated throughout the period of alveolar hypoxia in all six animals and postmortem studies showed that the lungs were not dehydrated. We injected intravenously radioactive albumin and measured its uptake in lymph and we observed no evidence of increased microvascular permeability to protein even after prolonged hypoxia.

We conclude that alveolar hypoxia increases transvascular fluid filtration in the newborn lamb by increasing hydraulic pressure in the microcirculation. The increase in fluid filtration is independent of changes in pleural pressure and the partial pressure of carbon dioxide in the inspired gas.

\section{MATERIALS AND METHODS}

Surgical preparation. Surgical preparation of the lambs is described in detail elsewhere $(4,40)$. Briefly, we operated on each lamb twice, first within $48 \mathrm{~h}$ of birth and again 7-10 d later. For both procedures, we anesthetized the lambs with halothane and nitrous oxide and used a piston type respirator for mechanical ventilation. Before and after surgery we kept the lambs with their mothers for feeding and warmth.

During the first operation, we inserted polyvinyl catheters into the left carotid artery and jugular vein through an incision in the neck, and we advanced the catheters until their tips were in the thoracic aorta and right atrium respectively. Through a left thoracotomy we placed a polyvinyl catheter directly into the left atrium and both a polyvinyl catheter and a 3.5 French thermodilution thermistor (Gould Statham, Hato Rey, PR) into the main pulmonary artery.

During the second operation, a right thoracotomy, we resected the systemic contributions to the caudal mediastinal lymph node and inserted a polyvinyl catheter, impregnated with heparin (TDMAC Processing, Polyscience, Inc., Warrington, PA), into the efferent duct of that node. In addition, we placed a $3 \times 3 \mathrm{~cm}$ 
silicone balloon (Silastic, Dow Corning Corp., Midland, MI) in the pleural space for subsequent measurements of pleural pressure. We allowed the lambs at least $3 \mathrm{~d}$ to recover from surgery before starting experiments.

Constant ventilation experiments. The 12 lambs studied during the first set of experiments weighed $8.4 \pm 0.7 \mathrm{~kg}$ and were $24 \pm$ $1 \mathrm{~d}$ old. At the beginning of the studies the lambs received sodium pentobarbital intravenously, $20 \mathrm{mg} / \mathrm{kg}$ body weight. This was followed by endotracheal intubation with a cuffed tube and mechanical ventilation with a piston type respirator (model 607 , Harvard Apparatus Co., Inc., Millis, MA). The respiratory rate was fixed at 60 breaths/min and tidal volume was adjusted to maintain the arterial $\mathrm{PCO}_{2}$ between 35 and 40 torr. Tidal volume and respiratory rate then remained constant as each lamb was studied during ventilation with air, then during ventilation with $10-14 \% \mathrm{O}_{2}$ in nitrogen. Throughout the study, the lambs rested on a canvas sling that did not interfere with respiratory movements, and they received sodium pentobarbital intravenously, 6 $\mathrm{mg} / \mathrm{kg}$ body weight, every $30 \mathrm{~min}$ for anesthesia. They also received isotonic saline intravenously, approximately $5 \mathrm{ml} / \mathrm{h}$ per $\mathrm{kg}$ body weight, an amount that caused no significant change in body weight, vascular pressures, or plasma protein concentrations.

Prolonged hypoxia experiments. The lambs studied during the second set of experiments weighed $7.9 \pm 0.6 \mathrm{~kg}$ and were $18 \pm$ $1 \mathrm{~d}$ old. In these studies the lambs were awake and unmedicated. Inspired gas mixtures flowed through a plastic bag placed around the head of the lambs. They breathed air for a 2-4-h control period, then $9-11 \% \mathrm{O}_{2}$ in nitrogen for $2-3 \mathrm{~h}$, and then $8-11 \%$ $\mathrm{O}_{2}$ and $3-5 \% \mathrm{CO}_{2}$ in nitrogen for 8-10 h. The total duration of alveolar hypoxia was at least $12 \mathrm{~h}$ in every experiment.

During experiments we measured vascular and pleural pressures continuously, and heart rate, respiratory rate, cardiac output and arterial $\mathrm{pH}, \mathrm{PO}_{2}$ and $\mathrm{PCO}_{2}$ at frequent intervals. In addition, we collected samples of lung lymph every $30 \mathrm{~min}$ and measured their volume to the nearest $0.01 \mathrm{ml}$. We obtained samples of aortic blood hourly. Pulmonary arterial, left atrial, and aortic pressures were measured with Statham P23Db strain gauge manometers (Statham Instruments, Hato Rey, PR) and pleural pressure was measured with a Statham PM131TC differential pressure transducer. The zero reference for vascular pressures was the level of the left atrium; for measurement of pleural pressure, zero reference was atmospheric pressure. Pressures were recorded using a Grass 7D 8-channel amplifier recorder (Grass Instruments, Quincy, MA). Heart and respiratory rates were obtained from phasic recordings of aortic and pleural pressures. Cardiac output was determined by indicator dilution, either with green dye (Hynson, Wescott, and Dunning, Inc., Baltimore, MD) or cold saline (34).

We calculated pulmonary vascular resistance as the difference between pulmonary arterial and left atrial pressures, divided by the cardiac output. Arterial $\mathrm{pH}, \mathrm{PO}_{2}, \mathrm{PCO}_{2}$, and inspired gas tensions were measured with a Corning Blood Gas Analyzer (Corning Glass Works, Medfield, MA).

In the six prolonged hypoxia studies, we did tracer studies with radioiodinated albumin during the control period and again after $10 \mathrm{~h}$ of hypoxia. For this procedure, we first obtained two baseline samples of blood and lymph. Then, we injected 2-3 $\mu \mathrm{Ci} / \mathrm{kg}$ of $\left.{ }^{125} \mathrm{I}\right]$ human albumin (Mallinkrodt, Saint Louis, MO) into the right atrium and collected samples of lymph every 15 min for $2-3 \mathrm{~h}$ and samples of aortic blood at the mid-point of each collection period.

Analytic methods. We centrifuged samples of blood and lymph and measured in the supernatant fluids concentrations of protein by the biuret method (13) and albumin by cellulose acetate electrophoresis (Microzone 110, Beckman Instruments, Inc., Fullerton, $\mathrm{CA}$ ).

For the radioactive tracer experiments we transferred $0.1 \mathrm{ml}$ of each sample of lymph and plasma into test tubes and measured the radioactivity within each sample for one min in a Searle 512 multichannel pulse-height analyzer (Searle Analytic, Inc., Des Plaines, IL). To calculate the specific activity for each sample we divided the number of counts per minute by the concentration of albumin in the sample. We then plotted the ratio of lymph specific activity to plasma specific activity as a function of time, drew a regression line through the points, and from that plot determined the time required for the specific activity in lymph to reach one-half that of plasma $\left(\mathrm{T}_{1 / 2}\right)$.

Postmortem studies. At the conclusion of the second set of experiments we intravenously anesthetized three of the lambs with sodium pentobarbital, $30 \mathrm{mg} / \mathrm{kg}$, inserted a cuffed tube into their trachea, ventilated their lungs with $9-11 \% \mathrm{O}_{2}$ and $3-5 \%$ $\mathrm{CO}_{2}$ in nitrogen and immediately resected their lungs at an inflation pressure of $25 \mathrm{~cm} \mathrm{H} \mathrm{H}_{2} \mathrm{O}$. We rapidly froze a small portion of the inflated tissue in liquid nitrogen for examination under a microscope. We homogenized the remaining lung to measure extravascular water content by a modification (11) of the method of Pearce et al. (31).

Statistical analysis. To compare measurements in the control period with those obtained during alveolar hypoxia, we used a paired $t$ test, corrected for multiple comparisons when applicable, and considered $P<0.05$ indicative of a significant difference (36). We expressed all data in the text as the mean \pm 1 SEM.

\section{RESULTS}

Hypoxia in anesthetized ventilated lambs. During anesthesia and constant ventilation at a respiratory frequency of $60 / \mathrm{min}$, alveolar hypoxia had no significant effect on arterial $\mathrm{pH}, \mathrm{PCO}_{2}$, heart rate or pleural pressure (Table 1). Systemic arterial pressure consistently decreased by an average of 10 torr; systemic venous pressure did not change.

Mean pulmonary artery pressure increased on average by $68 \%$ but cardiac output and left atrial pressure were unaffected by hypoxia. As pulmonary vascular resistance increased by $76 \%$ during hypoxia, average lung lymph flow increased by $75 \%$ and the concentration of protein in lymph decreased without any change in plasma protein concentration (Table 2, Fig. 1).

Prolonged hypoxia in spontaneously breathing lambs. As expected, alveolar hypoxia, without added carbon dioxide, decreased arterial $\mathrm{PCO}_{2}$ and increased arterial $\mathrm{pH}$ of unanesthetized lambs (Table 3). It also increased heart rate, respiratory rate, and phasic pleural pressure but did not cause a significant change in mean pleural pressure, aortic pressure, or systemic venous pressure. Addition of carbon dioxide to the inspired gas increased arterial $\mathrm{PCO}_{2}$, respiratory rate, and phasic pleural pressure; arterial $\mathrm{pH}$ and mean pleural pressure decreased, and mean aortic pressure increased. Metabolic acidosis did not develop in any of the lambs during the $12 \mathrm{~h}$ of hypoxia.

Alveolar hypoxia increased mean pulmonary artery pressure on average by $75 \%$, without influencing left atrial pressure. The $50 \%$ increase in pulmonary vascular resistance was associated with a $75 \%$ increase in lymph flow and a decrease in lymph protein concentration (Table 4, Fig. 2).

Addition of carbon dioxide to the inspired gas increased pulmonary artery pressure by an additional $33 \%$ and cardiac output by $14 \%$. In four of the six lambs, addition of carbon dioxide to the inspired gas increased lymph flow transiently (Fig. 2). After $1 \mathrm{~h}$ of supplemental carbon dioxide however, lymph flow decreased to a rate not significantly different from that measured during hypoxia alone.

Throughout the $12 \mathrm{~h}$ of hypoxia measurements of lung lymph flow were always greater than those obtained during the air breathing baseline. Lymph protein concentration decreased steadily during successive stages of alveolar hypoxia but it reached a steady state after a total of 4-5 h of hypoxia. Plasma protein concentration remained constant. The ratio of albumin to globulin in lymph did not change significantly before and during hypoxia $(1.47 \pm 0.10$ versus $1.40 \pm 0.10)$.

Figure 3 shows the results of one radioactive tracer study. After 
Table 1. Cardiorespiratory variables in 12 anesthetized, ventilated lambs before and during hypoxia*

\begin{tabular}{|c|c|c|c|c|c|c|c|}
\hline \multirow[b]{2}{*}{ Inspired gas } & \multirow{2}{*}{$\begin{array}{l}\mathrm{PaO}_{2} \\
\text { (torr) }\end{array}$} & \multirow{2}{*}{$\begin{array}{l}\mathrm{PaCO}_{2} \\
\text { (torr) }\end{array}$} & \multirow[b]{2}{*}{$\mathrm{pH}$} & \multirow[b]{2}{*}{ Heart rate } & \multirow{2}{*}{$\begin{array}{c}\text { Mean aortic } \\
\text { pressure } \\
\text { (torr) }\end{array}$} & \multicolumn{2}{|c|}{ Pleural pressure (torr) } \\
\hline & & & & & & Mean & Phasic \\
\hline $10-14 \%$ & $\begin{array}{l}91 \\
\pm 3 \\
35 \dagger \\
\pm 2 \\
\end{array}$ & $\begin{array}{c}38 \\
\pm 1 \\
37 \\
\pm 1 \\
\end{array}$ & $\begin{array}{r}7.44 \\
\pm 0.01 \\
7.41 \\
\pm 0.04 \\
\end{array}$ & $\begin{array}{c}212 \\
\pm 9 \\
220 \\
\pm 10\end{array}$ & $\begin{array}{c}100 \\
\pm 2 \\
90 \dagger \\
\pm 3\end{array}$ & $\begin{array}{l}-2 \\
\pm 0.5 \\
-2 \\
\pm 0.5\end{array}$ & $\begin{array}{c}2 \\
\pm 0.5 \\
2 \\
\pm 0.5\end{array}$ \\
\hline
\end{tabular}

$\dagger$ Different from control (air breathing), $P<0.05$.

Table 2. Lung fluid filtration in 12 anesthetized ventilated lambs before and during hypoxia*

\begin{tabular}{|c|c|c|c|c|c|c|c|}
\hline \multirow[b]{3}{*}{ Inspired gas } & \multirow{2}{*}{\multicolumn{2}{|c|}{ Vascular pressures (torr) }} & \multirow{3}{*}{$\begin{array}{c}\text { Cardiac } \\
\text { output } \\
\left(\mathrm{ml} \cdot \mathrm{kg}^{-1} \cdot \mathrm{min}^{-1}\right)\end{array}$} & \multirow{3}{*}{$\begin{array}{c}\text { Lung } \\
\text { lymph } \\
\text { flow } \\
(\mathrm{ml} / \mathrm{h})\end{array}$} & \multicolumn{3}{|c|}{ Protein concentration $(\mathrm{g} / \mathrm{dl})$} \\
\hline & & & & & \multirow[b]{2}{*}{ Lymph } & \multirow[b]{2}{*}{ Plasma } & \multirow{2}{*}{$\frac{\text { Lymph }}{\text { Plasma }}$} \\
\hline & $\overline{\mathrm{P}} \mathrm{pa}$ & $\overline{\mathrm{P}} \mathrm{la}$ & & & & & \\
\hline \multirow[t]{2}{*}{ Air } & 19 & 4 & 252 & 2.20 & 3.4 & 5.4 & 0.64 \\
\hline & \pm 1 & \pm 1 & \pm 16 & \pm 0.34 & \pm 0.1 & \pm 0.1 & \pm 0.01 \\
\hline \multirow[t]{2}{*}{$10-14 \% \mathrm{O}_{2}$} & $32 \dagger$ & 4 & 269 & $3.83 \dagger$ & $2.8 \dagger$ & 5.3 & $0.54 \uparrow$ \\
\hline & \pm 2 & \pm 1 & \pm 25 & \pm 0.36 & \pm 0.2 & \pm 0.1 & \pm 0.01 \\
\hline
\end{tabular}

* Values expressed as mean \pm SEM

$\dagger$ Different from control (air breathing), $P<0.05$.

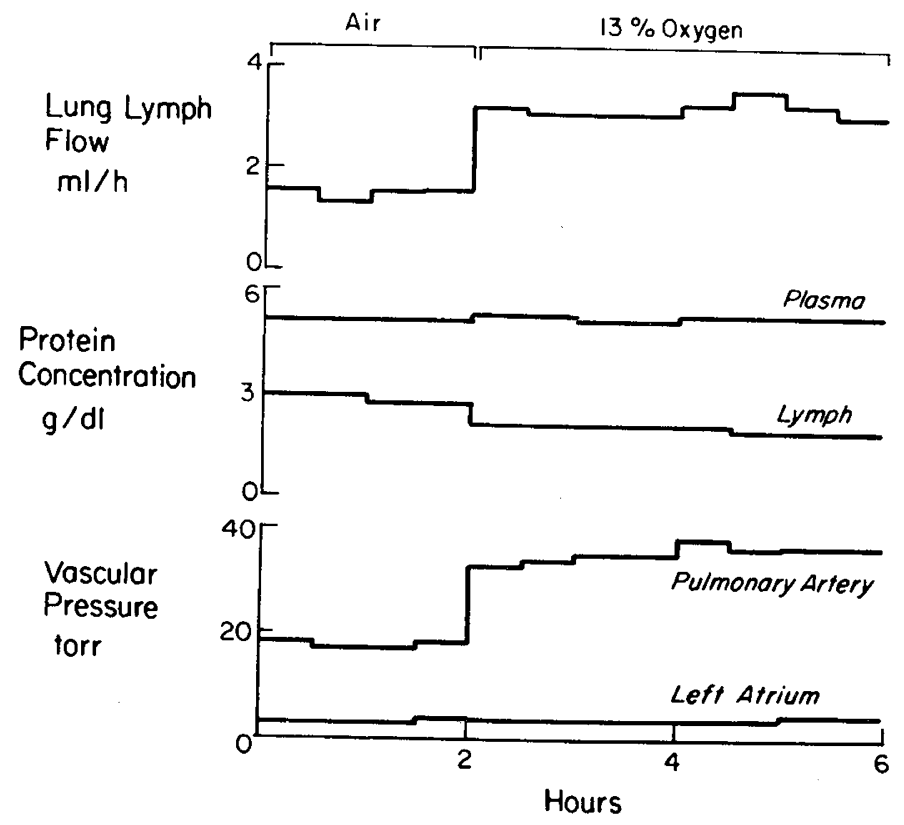

Fig. 1. Time course of one experiment done with an anesthetized lamb during constant ventilation. Hypoxia abruptly increased pulmonary artery pressure and lung lymph flow and decreased the lymph protein concentration without affecting left atrial pressure or plasma protein concentration.

injection of $\left[{ }^{125} I\right]$ albumin, the specific activity of albumin in lymph relative to plasma increased linearly as a function of time for the six lambs that we studied, and $T_{1 / 2}$ was not significantly different during prolonged hypoxia than it was during the control period $(130 \pm 7$ versus $125 \pm 11 \mathrm{~min})$.

In the three lambs killed after $12 \mathrm{~h}$ of hypoxia, extravascular lung water content per gram of dry lung tissue was not significantly different from that of control lambs $(4.65 \pm 0.28$ versus $4.72 \pm 0.14)(4)$. Lung blood content per gram of dry lung tissue was significantly less than that of controls $(1.32 \pm 0.25$ versus $2.22 \pm 0.25)$ (4). Photomicrographs of frozen sections of lung showed no evidence of alveolar or interstitial edema.

\section{DISCUSSION}

Despite changes in experimental design our results are very similar to those reported previously by Bressack and Bland $(5$, 6): alveolar hypoxia increases pulmonary artery pressure and lung lymph flow and decreases the concentration of protein in lymph. If we assume that the concentration of protein in lymph approximates that in the pulmonary interstitium, as others have shown $(30,44)$, then measurement of lung lymph flow and the concentration of protein in lymph provides a sensitive index of net transvascular movement of fluid and protein in the lung (4, $8,39,40$ ). Our results, therefore, suggest that alveolar hypoxia increases net transvascular filtration of fluid into the lungs of lambs. The associated decrease in the concentration of protein in lymph relative to that in plasma suggests that the increased filtration of fluid is the result of increased filtration pressure in the microcirculation of the lung.

Our first set of experiments was specifically designed to see if changes in the pattern of breathing induced by alveolar hypoxia played any part in this observed increase in lung lymph flow. Bressack and Bland $(5,6)$ noted that during alveolar hypoxia the lambs breathed more deeply and mean pleural pressure decreased. Previous reports $(14,21,27,38,45)$ have suggested that a decrease in pleural pressure may result in a decrease in interstitial pressure, which in turn might be expected to increase fluid filtration, at least in extra-alveolar vessels (1).

In our 12 anesthetized lambs, lymph flow increased during alveolar hypoxia and lymph protein concentration decreased despite a constant breathing pattern and pleural pressure. We conclude that the increase in filtration pressure induced by alveolar hypoxia in the newborn lamb is the direct result of an increase in microvascular hydraulic pressure and is independent of any change in interstitial pressure caused by altered pleural pressure or patterns of breathing.

Bressack and Bland $(5,6)$ also noted that the hyperventilation induced by alveolar hypoxia resulted in respiratory alkalosis. Both arterial $\mathrm{PCO}_{2}$ and $\mathrm{pH}$ affect pulmonary vascular resistance and may influence the response of the pulmonary vasculature to hypoxia $(20,25,35)$. Our second set of experiments was designed to examine the effect of arterial $\mathrm{PCO}_{2}$ and $\mathrm{pH}$ on the increase in lymph flow observed during alveolar hypoxia. In these experiments addition of carbon dioxide to the inspired gas mixture increased arterial $\mathrm{PCO}_{2}$ and decreased arterial $\mathrm{pH}$ but did not 
Table 3. Cardiorespiratory variables in six unanesthetized spontaneously breathing lambs before and during prolonged hypoxia*

\begin{tabular}{|c|c|c|c|c|c|c|c|c|}
\hline \multirow[b]{2}{*}{ Inspired gas } & \multirow[b]{2}{*}{$\begin{array}{l}\mathrm{PaO}_{2} \\
\text { (torr) }\end{array}$} & \multirow[b]{2}{*}{$\begin{array}{l}\mathrm{PaCO}_{2} \\
\text { (torr) }\end{array}$} & \multirow[b]{2}{*}{$\mathrm{pH}$} & \multirow[b]{2}{*}{ Heart rate } & \multirow[b]{2}{*}{$\begin{array}{c}\text { Respiratory } \\
\text { rate }\end{array}$} & \multirow{2}{*}{$\begin{array}{l}\text { Mean aortic } \\
\text { pressure } \\
\text { (torr) }\end{array}$} & \multicolumn{2}{|c|}{ Pleural pressure (torr) } \\
\hline & & & & & & & Mean & Phasic \\
\hline \multirow[t]{2}{*}{ Air } & 91 & 42 & 7.43 & 206 & 60 & 86 & -2 & 4 \\
\hline & \pm 4 & \pm 1 & \pm 0.01 & \pm 8 & \pm 6 & \pm 2 & \pm 0.5 & \pm 1 \\
\hline \multirow[t]{2}{*}{$9-11 \% \mathrm{O}_{2}$} & $35 \dagger$ & $32 \dagger$ & $7.50 \dagger$ & $241 \dagger$ & $79 \dagger$ & 88 & -2 & $7 \dagger$ \\
\hline & \pm 2 & \pm 2 & \pm 0.03 & \pm 7 & \pm 8 & \pm 2 & \pm 0.5 & \pm 1 \\
\hline $\begin{array}{l}8-11 \% \mathrm{O}_{2} \\
3-5 \% \mathrm{CO}_{2}\end{array}$ & $\begin{array}{r}36 \\
\pm 1\end{array}$ & $\begin{array}{l}40 \ddagger \\
\pm 1\end{array}$ & $\begin{array}{r}7.39 \ddagger \\
\pm 0.01\end{array}$ & $\begin{aligned} & 232 \dagger \\
\pm & 7\end{aligned}$ & $\begin{array}{l}116 \dagger \ddagger \\
\pm 11\end{array}$ & $\begin{array}{l}99 \dagger \ddagger \\
\pm 3\end{array}$ & $\begin{array}{l}-3 \dagger \\
\pm 0.5\end{array}$ & $\begin{array}{l}14 \nmid \ddagger \\
\pm 1\end{array}$ \\
\hline
\end{tabular}

* Values expressed as mean \pm SEM.

$\dagger$ Different from control (air breathing), $P<0.05$.

$\ddagger$ Different from $9-11 \% \mathrm{O}_{2}, P<0.05$.

Table 4. Lung fluid filtration in six unanesthetized spontaneously breathing lambs before and during prolonged hypoxia*

\begin{tabular}{|c|c|c|c|c|c|c|c|}
\hline \multirow[b]{3}{*}{ Inspired gas } & \multirow{2}{*}{\multicolumn{2}{|c|}{ Vascular pressures (torr) }} & \multirow{3}{*}{$\begin{array}{c}\text { Cardiac } \\
\text { output } \\
\left(\mathrm{ml} \cdot \mathrm{kg}^{-1} \cdot \mathrm{min}^{-1}\right)\end{array}$} & \multirow{3}{*}{$\begin{array}{l}\text { Lung } \\
\text { lymph } \\
\text { flow } \\
(\mathrm{ml} / \mathrm{h})\end{array}$} & \multicolumn{3}{|c|}{ Protein concentration $(\mathrm{g} / \mathrm{dl})$} \\
\hline & & & & & \multirow[b]{2}{*}{ Lymph } & \multirow[b]{2}{*}{ Plasma } & \multirow{2}{*}{$\frac{\text { Lymph }}{\text { Plasma }}$} \\
\hline & $\overline{\mathrm{P}} \mathrm{pa}$ & $\overline{\bar{P}} \mathrm{la}$ & & & & & \\
\hline \multirow{2}{*}{ Air } & 17 & 3 & 292 & 1.74 & 3.8 & 5.7 & 0.65 \\
\hline & \pm 1 & \pm 1 & \pm 39 & \pm 0.26 & \pm 0.1 & \pm 0.1 & \pm 0.01 \\
\hline \multirow{2}{*}{$9-11 \% \mathrm{O}_{2}$} & $30 \dagger$ & 3 & $375 \dagger$ & $3.05 \dagger$ & $3.4 \dagger$ & 5.8 & $0.58 \dagger$ \\
\hline & \pm 1 & \pm 1 & \pm 45 & \pm 0.33 & \pm 0.1 & \pm 0.1 & \pm 0.02 \\
\hline $8-11 \% \mathrm{O}_{2}$ & $37 \dagger \ddagger$ & 4 & $429 \dagger$ & $3.28 \dagger$ & $3.1+$ & 5.8 & $0.52 \dagger+$ \\
\hline $3-5 \% \mathrm{CO}_{2}$ & \pm 1 & \pm 1 & \pm 43 & \pm 0.42 & \pm 0.1 & \pm 0.1 & \pm 0.02 \\
\hline
\end{tabular}

$*$ Values expressed as mean $\pm \mathrm{SEM}$.

$\uparrow$ Different from control (air breathing), $P<0.05$.

$\$$ Different from $9-11 \% \mathrm{O}_{2}, P<0.05$.

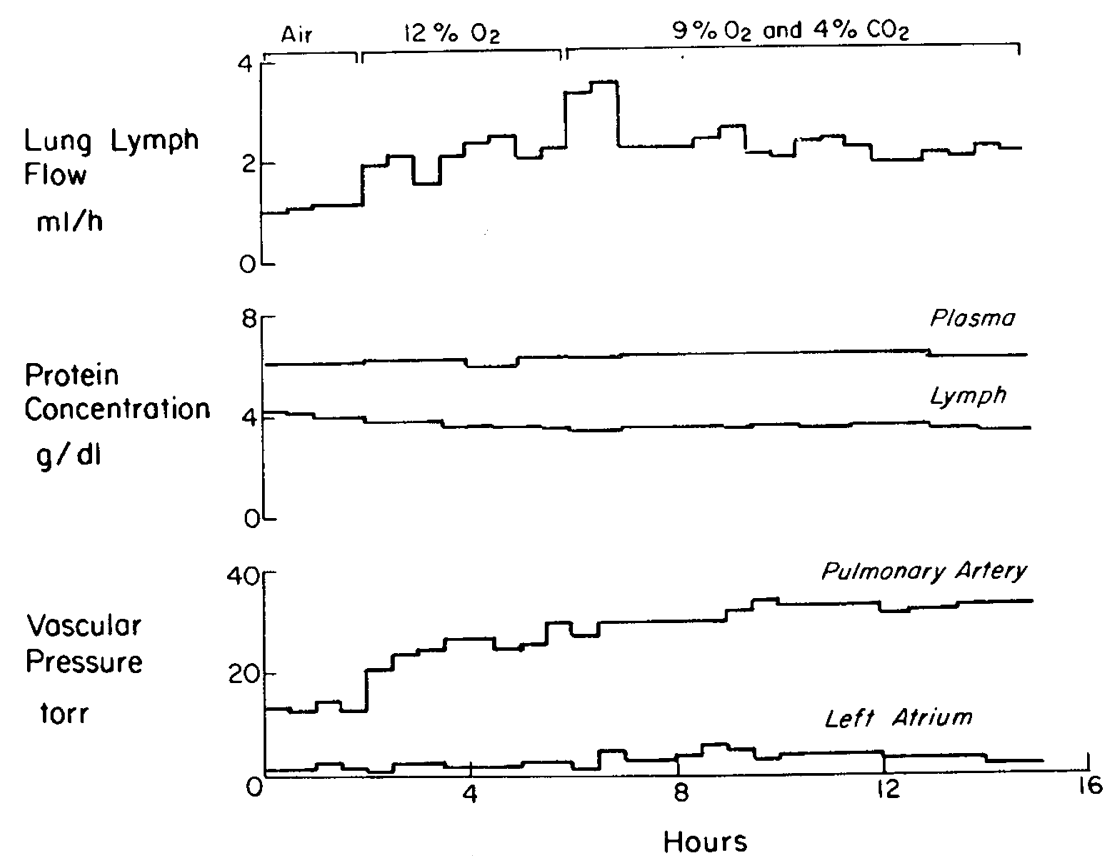

Fig. 2. Time course of one long hypoxia experiment done with an unanesthetized lamb that breathed spontaneously and received no medication. During alveolar hypoxia alone, pulmonary artery pressure and lymph flow increased, and the concentration of protein in lymph decreased. With addition of $\mathrm{CO}_{2}$ to the inspired gas, pulmonary artery pressure increased again, but lymph flow increased only transiently. Lymph flow remained greater than the control rate for the duration of hypoxia.

change steady state lung fluid balance. Although both pulmonary artery pressure and pulmonary blood flow increased, the resultant increase in microvascular hydraulic pressure was offset by a concomitant decrease in interstitial protein osmotic pressure, reflected by the decrease in lymph protein concentration. These results are similar to those of Haberkern and Bland (16) who reported that respiratory acidosis without hypoxia had no effect on steady state lung lymph flow in lambs.

None of the lambs developed metabolic acidosis during the period of sustained hypoxia. All were otherwise healthy and wellhydrated and we presume that oxygen delivery to the tissues was maintained by the observed increase in cardiac output. 


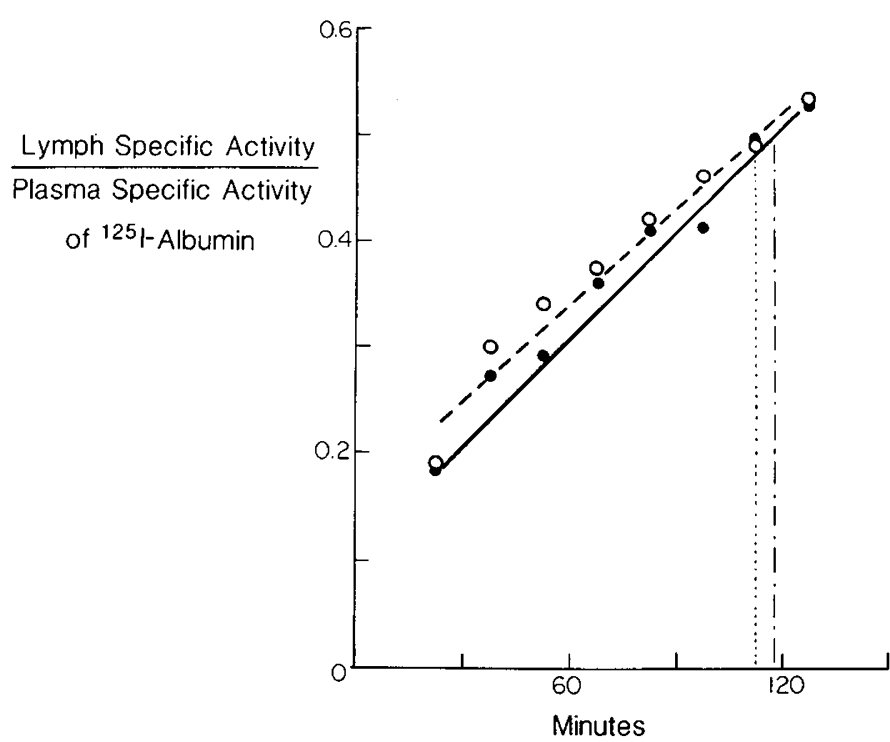

Fig. 3. Lymph:plasma specific activity of $\left[{ }^{125} \mathrm{I}\right]$ albumin as a function of time after intravascular injection of the radioactive tracer in one lamb. The time required for half equilibration decreased only slightly (from 118 to $112 \mathrm{~min}$ ) during hypoxia (—), control and (O---O), hypoxia.

In four of the six lambs, as carbon dioxide was added to the inspired gas, lymph flow increased acutely and remained elevated for 30-60 min, as the concentration of protein in the lymph decreased. These changes suggest that microvascular filtration pressure increased at least transiently. When carbon dioxide was added to the inspired gas, all of the lambs began to struggle and bleat. This period of agitation lasted $30-60 \mathrm{~min}$ and was associated with frequent brief increases in both pulmonary artery and left atrial pressures. These transient increases in vascular pressure may have led to transient increases in filtration pressure and lymph flow. Haberkern and Bland (16) noted similar transient increases of lymph flow in lambs during hypercapnia alone and they postulated that the increase was the result of agitation. The transient nature of the change emphasizes the importance of prolonging experiments that are designed to assess changes in lung fluid filtration.

The sustained hypoxia experiments also were designed to examine the possibility that hypoxia might decrease intracellular fluid in the lung, thereby diluting interstitial protein and increasing lymph flow. If this were so, prolonged hypoxia would have caused progressive dehydration of the lungs, and lymph flow should have decreased over time. We found, however, that lymph flow remained up throughout the 12-h period of alveolar hypoxia. During this $12-\mathrm{h}$ period, total lymph flow exceeded that of the baseline period by approximately $20 \mathrm{ml}$. If we assume that we were collecting only two-thirds of total lung lymph (18), then at least $30 \mathrm{ml}$ of water must have left the lung during the period of hypoxia. This degree of dehydration would have reduced postmortem lung water from an average control value of 4.7 (4) to $3.8 \mathrm{~g} / \mathrm{g}$ dry lung tissue, an amount considerably less than the $4.65 \mathrm{~g} / \mathrm{g}$ of dry lung that we measured for the three lambs killed after $12 \mathrm{~h}$ of hypoxia. Lung dehydration, therefore, cannot account for the increase in lymph flow that we observed. We conclude that the increased lymph flow that occurs during alveolar hypoxia represents an increase in fluid filtration from the microcirculation, probably the result of an increase in microvascular hydraulic pressure.

Several authors have shown that diaphragmatic lymphatics may contribute substantially to the lymph collected from the caudal mediastinal lymph node of the sheep $(10,33)$. Drake $e t$ al. (10) showed that the contribution of these lymphatics to overall lymph flow increased with increasing diaphragmatic movement. If the increase in lymph flow that we observed during alveolar hypoxia in the spontaneously breathing lamb were the result of increased diaphragmatic movement; i.e., increased nonpulmonary lymph flow, then the response should have been attenuated by constant ventilation under anesthesia. It was not. Roos et al. (33) showed that non-pulmonary contamination of caudal mediastinal lymph increased with increasing systemic venous pressure. In their study, however, when lymph flow increased the lymph to plasma protein ratio also increased. In both of our experiments, systemic venous pressure remained constant before and during alveolar hypoxia and the lymph to plasma protein ratio always decreased as lymph flow increased.

We also examined the effects of prolonged hypoxia on lung microvascular permeability to protein. The results of our albumin tracer studies indicate that hypoxia does not influence endothelial permeability to protein, inasmuch as $T_{1 / 2}$ did not decrease significantly (41). To further evaluate our data for evidence of a permeability change we plotted lymph:plasma protein ratio as a function of the lymph flow rate for the six lambs studied before and during alveolar hypoxia (Fig. 4). We compared the results with those from two other sets of experiments, also done in our lab: in one set, we increased lymph flow by inflating a balloon in the left atrium of seven lambs, so that filtration pressure in the pulmonary microcirculation increased by approximately 10 torr (3); in the second set, lymph flow was increased by putting the lambs in $100 \%$ oxygen for $3-5 \mathrm{~d}(7)$. During studies in which lung microvascular pressure was increased by left atrial hypertension, lymph flow increased but the lymph:plasma protein ratio decreased. During hyperoxia studies, in which lung microvascular permeability to protein increased, the lymph:plasma protein ratio increased as lymph flow increased. During our hypoxia studies, the increase in lymph flow was accompanied by a decrease in the lymph:plasma protein ratio that was virtually identical to those observed when filtration pressure was increased by inflation of a balloon in the left atrium. The response was clearly different from that seen when microvascular permeability to protein was increased by oxygen toxicity.

If hypoxia had damaged the microvascular membrane, the sieving properties of the pulmonary microcirculation might have changed, causing a decrease in the ratio of albumin:globulin in lymph $(7,8)$. This did not occur. We conclude that prolonged hypoxia does not alter microvascular permeability to protein.

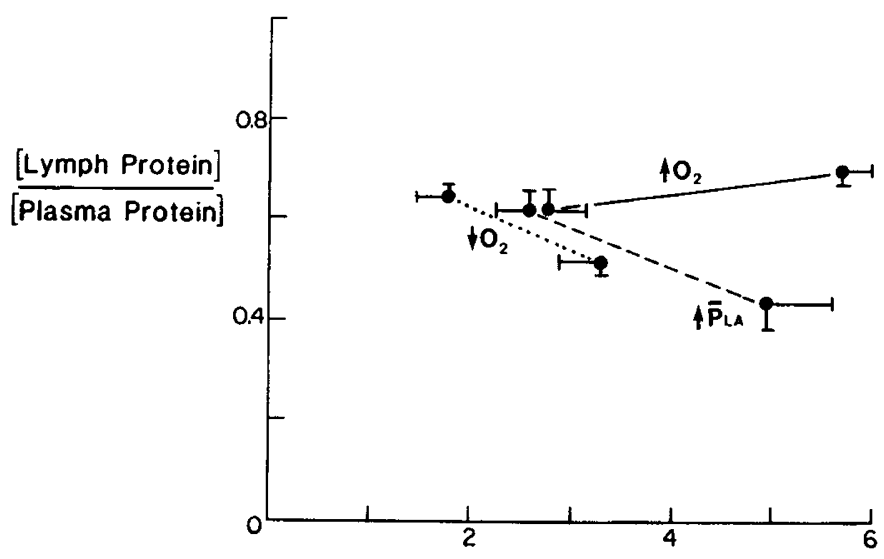

Lung Lymph Flow $(\mathrm{ml} / \mathrm{h})$

Fig. 4. Test for differences in lung microvascular permeability to protein in lambs. When elevated lung microvascular pressure $(\uparrow \mathrm{Pla}$ : inflated left atrial balloon) increases lymph flow, the lymph:plasma protein ratio decreases. When continuous oxygen breathing $\left(\uparrow \mathrm{O}_{2}\right)$ for 5 d causes a permeability change, lymph flow also increases, but the lymph:plasma protein ratio increases. During hypoxia $\left(\downarrow \mathrm{O}_{2}\right)$ as lymph flow increases the lymph:plasma protein ratio decreases, just as it does when filtration pressure increases. 
Our results are very similar to those reported recently by Mitzner and Sylvester (28), who studied the effects of hypoxia on the relationship between pulmonary blood flow, pulmonary artery pressure, and fluid filtration in isolated, blood perfused pig lungs. They found that under normoxemic conditions, pulmonary artery pressure and fluid filtration increased as pulmonary blood flow increased. Alveolar hypoxia caused an even greater increase in both pulmonary artery pressure and fluid filtration at each increment of pulmonary blood flow. They used a simple Starling resistor model of the lung to explain their results. According to this model, the pulmonary circulation is comprised of recruitable parallel channels, each with its own filtration coefficient and critical pressure. As pulmonary blood flow increases, parallel channels with higher critical pressures are recruited and pulmonary arterial pressure increases. Hypoxia increases pulmonary artery pressure by increasing the critical pressure in each of the parallel channels. To account for the effects of blood flow and hypoxia on fluid filtration, the authors assumed that the locus of critical pressure was downstream from the site of transvascular fluid filtration. Within such a model, as blood flow increases and opens parallel channels with higher critical pressures, overall filtration pressure and entry of fluid into the lung would be expected to increase. The effect of hypoxia, therefore, would be to increase all of the critical pressures, which in turn would increase filtration pressure at any given rate of pulmonary blood flow.

Recent work by Capen and co-workers (9) supports this capillary recruitment theory as an explanation for the increased fluid filtration observed during hypoxia. They studied the effects of hypoxia on the pulmonary circulation of dogs, and with in vivo microscopy demonstrated pulmonary capillary recruitment near the surface of the lung during alveolar hypoxia. In addition they found that the diffusing capacity for carbon monoxide increased during hypoxia, which they cited as evidence that capillary recruitment was a generalized phenomena and not just localized to the pleural surface.

Data from other investigators, however, does not support the theory of widespread capillary recruitment. Stahlman et al. (37) used indicator dilution curves to estimate pulmonary blood volume in lambs and found a significant reduction during hypoxia. Our data and that of Bressack and Bland $(5,6)$ show that hypoxia decreases total lung blood content in lambs. Vreim and Staub (43) showed that the pulmonary capillary blood volume of anesthetized cats did not change during alveolar hypoxia.

In addition, the model proposed by Mitzner and Sylvester requires that the locus of critical tone in the pulmonary circulation be downstream from the site of fluid filtration. If most fluid exchange in the lung occurs in the capillaries then this site of critical tone would have to be in pulmonary venules. Although several investigators have presented evidence for hypoxia induced pulmonary venous constriction in both dogs $(29,32)$ and cattle (23), Hyman and Kadowitz (20) found no evidence of pulmonary venous constriction during alveolar hypoxia in lambs that were 3-mo-old. They and other investigators have concluded that alveolar hypoxia constricts predominantly arteriolar vessels in the lung $(2,12,22,26)$. If the site of critical tone is in the pulmonary arteriole, then the site of fluid filtration would have to be in small pulmonary arterioles, as postulated by Whayne and Severinghaus (46). The total contribution of these vessels to the observed increase in fluid filtration during alveolar hypoxia would be limited by their relatively thick walls and limited surface area (39).

An alternative explanation for the effects of hypoxia on pulmonary artery pressure and lung fluid balance is that hypoxia closes (i.e., derecruits) selected parallel channels in the lung and redirects blood flow through the remaining open channels (17). In support of this theory Haab et al. (15) analyzed alveolararterial gradients for nitrogen and found that hypoxia exaggerates ventilation-perfusion imbalances. Viswanathan et al. (42) did perfusion lung scans of adults who had experienced high altitude pulmonary edema and found a patchy distribution of perfusion during hypoxia. Hyman (19) studied the effects of progressive derecruitment of lung vessels on pressure-flow relationships in pulmonary arteries and veins of dogs. He perfused selected segments of the lungs at varying flow rates and found that as segment size decreased pulmonary arterial and venous pressures increased at all rates of flow. In fact, the changes in pulmonary artery pressure-flow relationships that occurred with progressive derecruitment of the pulmonary vascular bed were very similar to that noted by Mitzner and Sylvester during alveolar hypoxia. Inasmuch as pulmonary venous pressure is a major determinant of filtration pressure in the lung, Hyman's finding of increased pulmonary venous pressure with decreasing segment size suggests that derecruitment of the pulmonary vascular bed at a constant blood flow could cause an increase in fluid filtration in the remaining open lung segments. Recently Landolt and associates (24) tested this hypothesis in sheep by resecting large segments of lung to reduce the size of the pulmonary vascular bed. They decreased lung mass by approximately $65 \%$ and maintained cardiac output by blood transfusions. In doing so they produced high-pressure pulmonary edema in the remaining lobes. The theory that hypoxia causes patchy closure of pulmonary vessels with redistribution of flow at higher filtration pressures in those vessels that remain open is compatible with previous data that suggests that the pulmonary vascular bed is constricted during alveolar hypoxia.

We conclude that in the newborn lamb alveolar hypoxia increases transvascular flow of fluid into the lungs by increasing filtration pressure. This causes lymph flow to increase and the concentration of protein in lymph to decrease without affecting microvascular permeability to protein.

\section{REFERENCES AND NOTES}

1. Albert, R. K., Lakshminaraayan, S., Huang, T. W., and Butler, J.: Fluid leaks from extra-alveolar vessels in living dog lungs. J. Appl. Physiol., 44: 476 (1977).

2. Bergofsky, E. H., Haas, F., and Porcelli, R.: Determination of the sensitive vascular sites from which hypoxia and hypercapnia elicit rises in pulmonary arterial pressure. Fed. Proc., 27: 1420 (1968).

3. Bland, R. D., Hansen, T. N., Hazinski, T. A., Haberkern, C. M., and Bressack, M. A.: Studies of lung fluid balance in newborn lambs. N. Y. Acad. Sci., 384: 126 (1982)

4. Bland, R. D. and McMillan, D. D.: Lung fluid dynamics in awake newborn lambs. J. Clin. Invest., 60: 1107 (1977)

5. Bland, R. D., Bressack, M. A., Haberkern, C. M., and Hansen, T. N.: Lung fluid balance in hypoxic, awake newborn lambs and mature sheep. Biol. Neonate, 38: 221 (1980).

6. Bressack, M. A. and Bland, R. D.: Alveolar hypoxia increases lung fluid filtration in unanesthetized newborn lambs. Circ. Res., 46: 111 (1980).

7. Bressack, M. A., McMillan, D. D., and Bland, R. D.: Pulmonary oxygen toxicity: increased microvascular permeability to protein in unanesthetized lambs. Lymphology, 12: 133 (1979).

8. Brigham, K. L., Woolverton, W. C., Blake, L. H., and Staub, N. C.: Increased sheep lung vascular permeability caused by pseudomonas bacteremia. J. Clin. Invest., 54: 792 (1975)

9. Capen, R. L., Latham, L. P., and Wagner, W. W.: Diffusing capacity of the lung during hypoxia: role of capillary recruitment. J. Appl. Physiol., 50: 165 (1981).

10. Drake, R., Adair, T., Traber, D., and Gabel, J.: Contamination of caudal mediastinal node efferent lymph in sheep. Am. J. Physiol., 241: H354 (1981).

11. Erdmann, A. J., Vaughan, T. R., Brigham, K. L., Woolverton, W. C., and Staub, N. C.: Effect of increased vascular pressure on lung fluid balance in unanesthetized sheep. Circ. Res., 37: 271 (1975).

12. Glazier, J. B. and Murray, J. F.: Sites of pulmonary vasomotor reactivity in the dog during alveolar hypoxia and serotonin and histamine infusions. J. Clin. Invest., 50:2550 (1971)

13. Gornall, A. G., Bardawill, G. J., and David, M. M.: Determination of serum proteins by means of the Biuret reaction. J. Biol. Chem., 177: 751 (1949).

14. Goshy, M., Lai-Fook, S. J., and Hyatt, R. E.: Perivascular pressure measurements by wick-catheter technique in isolated dog lobes. J. Appl. Physiol., 46. 950 (1979).

15. Haab, P., Held, D. R., Ernst, H., and Farhi, L. E.: Ventilation-perfusion relationships during high altitude adaptation. J. Appl. Physiol., 26: 77 (1969).

16. Haberkern, C. M. and Bland, R. D.: Effect of hypercapnia on net filtration of fluid in the lungs of awake newborn lambs. J. Appl. Physiol., 51: 423 (1981)

17. Hultgren, H. N. and Grover, R. F.: Circulation adaptation to high altitude. Ann. Rev. Med., 19: 119 (1968).

18. Humphreys, P. W., Normand, I. C. S., Reynolds, E. O. R., and Strang, L. B.: 
Pulmonary lymph flow and the uptake of liquid from the lungs of the lamb at the start of breathing. J. Physiol. (London), 193: 1 (1967).

19. Hyman, A. L.: Effects of large increases in pulmonary blood flow on pulmonary venous pressure. J. Appl. Physiol., 27: 179 (1969).

20. Hyman, A. L. and Kadowitz, P. J.: Effects of alveolar and perfusion hypoxia and hypercapnia on pulmonary vascular resistance in the lamb. Am. J. Physiol., 228: 397 (1975)

21. Inoue, H., Inoue, C., and Hildebrandt, J.: Vascular and airway pressures, and interstitial edema affect peribronchial fluid pressure. J. Appl. Physiol., 48: $177(1980)$

22. Kato, M. and Staub, N. C.: Response of small pulmonary arteries to unilobar hypoxia and hypercapnia. Circ. Res., 19: 426 (1966).

23. Kuida, H., Tsagaris, T. J., and Hecht, H. H.: Evidence for pulmonary venoconstriction in brisket disease. Circ. Res., 12: 182 (1963).

24. Landolt, C. C., Matthay, M., and Staub, N. C.: Lung resection, increased blood flow and high pressure in sheep. Failure to detect pore stretching or high linear flow injury. Microvasc. Res., 20: 117 (1980).

25. Malik, A. B. and Kidd, B. S. L.: Independent effects of changes in $\mathrm{H}^{+}$and $\mathrm{CO}_{2}$ concentrations on hypoxic pulmonary vasoconstriction. J. Appl. Physiol., 34: 318 (1973).

26. Malik, A. B. and Kidd, B. S. L.: Pulmonary arterial wedge and left atrial pressures and the site of hypoxic pulmonary vasoconstriction. Respiration, 33: 123 (1976).

27. Mellins, R. B., Levine, O. R., Skalak, R., and Fishman, A. F. Interstitial pressure of the lung. Circ. Res., 24: 197 (1969).

28. Mitzner, W. and Sylvester, J. T.: Hypoxic vasoconstriction and fluid filtration in pig lungs. J. Appl. Physiol., 51; 1065 (1981)

29. Morgan, B. C., Church, S. C., and Guntheroth, W. G.: Hypoxic constriction of pulmonary artery and vein in intact dogs. J. Appl. Physiol, 25:356 (1968).

30. Nicolaysen, G., Nicolaysen, A., and Staub, N. C.: A quantitative radioautographic comparison of albumin concentration in different sized lymph vessels in normal mouse lungs. Microvasc. Res., 10: 138 (1975).

31. Pearce, M. L., Yamashita, J., and Beazell, J.: Measurement of pulmonary edema. Circ. Res., 16; 482 (1965).

32. Rivera-Estrada, C., Saltzman, P. W., Singer, D., and Katz, L. N.: Action of hypoxia on the pulmonary vasculature. Circ. Res., 6: 10 (1958).

33. Roos, P. J., Albertine, K. H., Weiner-Kronish, J. P., Culver, P. L., and Staub, N. C.: Removal of portal system contribution to caudal mediastinal node $(\mathrm{CMN})$ efferent lymph in anesthetized sheep. Physiologist, 25: 311 (1981).

34. Rudolph, A. M.: Congenital Diseases of the Heart: Clinical-Physiologica Considerations in Diagnosis and Management. pp. 139-149 (Chicago, Year Book Medical Publishers, 1974).

35. Rudolph, A. M. and Yuan, S.: Response of the pulmonary vasculature to hypoxia and $\mathrm{H}^{+}$ion concentration changes. J. Clin. Invest., 45: 399 (1966).
36. Snedecor, G. W. and Cochran, W. G.: Statistical Methods, Ed. 6, pp. 91-119. (Ames Iowa State University Press, 1972).

37. Stahlman, M., Gray, J., Young, W. C., and Shepard, F. M.: Cardiovascular response of the neonatal lamb to hypoxia and hypercapnia. Am. J. Physiol., 213: 899 (1967)

38. Stalcup, S. A. and Mellins, R. B.: Mechanical forces producing pulmonary edema in acute asthma. N. Eng. J. Med., 297: 592 (1977).

39. Staub, N. C.: Pulmonary Edema. Physiol. Rev., 54: 678 (1974).

40. Staub, N. C., Bland, R. D., Brigham, K. L., Demling, R. H., Erdmann, A. J III, and Woolverton, W. C.: Preparation of chronic lung lymph fistulas in sheep. J. Surg. Res., 19: 315 (1975).

41. Vaughan, T. R., Erdmann, A. J., III, Brigham, K. L., Woolverton, W. C., Weidner, W. J., and Staub, N. C.: Equilibration of intravascular albumin with lung lymph in unanesthetized sheep. Lymphology, 12: 217 (1979).

42. Viswanathan, R., Subrumanian, S., and Radha, T. G.: Effect of hypoxia on regional lung perfusion by scanning. Respiration, 37: 142 (1979).

43. Vreim, C. E. and Staub, N. C.: Indirect and direct pulmonary capillary blood volume in anesthetized open-thorax cats. J. Appl. Physiol., 34:452 (1973).

44. Vreim, C. E., Snasnall, P. D., Demling, R. H., and Staub, N. C.: Lung lymph and free interstitial fluid protein composition in sheep with edema. Am.J. Physiol., 230: 1650 (1976).

45. Warren, M. F., Peterson, D. K., and Drinker, C. K.: The effects of heightened negative pressure in the chest, together with further experiments upon anoxia in increasing the flow of lung lymph. Am. J. Physiol., 137: 641 (1942).

46. Whayne, T. F. Jr. and Severinghaus, J. W.: Experimental hypoxic pulmonary edema in the rat. J. Appl. Physiol., 25: 729 (1968)

47. The authors wish to thank R. B. Goldberg and T. M. Chou for their technical assistance, $\mathrm{C}$. Oliphant and $\mathrm{M}$. Biagini for typing the manuscript and $\mathrm{M}$. H. Briscoe for drawing the figures.

48. Requests for reprints should be addressed to: Thomas N. Hansen, Department of Pediatrics, Baylor College of Medicine, 1200 Moursund Ave., Houston, TX 77030

49. Work presented in this paper was supported in part by National Heart, Lung and Blood Institute (NHLBI) Pulmonary Specialized Center of Research (SCOR) Grant HL 19185, and by U.S. Public Health Service Program Project Grants HL/HD 24056 and HL 25816. R. D. Bland did part of this work during his tenure as an Established Investigator of the American Heart Association. T. N. Hansen and T. A. Hazinski were Trainees supported by NHLBI Pulmonary Faculty Training Grant HL 07159. C. M. Haberkern received support from Grant HD 05709 awarded by the Institute for Child Health and Human Development of the National Institutes of Health. 50. Received for publication January 10,1983.

51. Accepted for publication June 3, 1983 .

\title{
Maternal Corticosteroid Therapy and the Fetal Brain in Experimental Hyaline Membrane Disease
}

\author{
S. M. SUMI, ${ }^{(28)}$ WILLIAM E. TRUOG III, AND DALE M. KESSLER
}

Laboratory of Neuropathology, Department of Pathology, Division of Neurology, Department of Medicine and the Child Development and Mental Retardation Center, University of Washington School of Medicine [S. M. S.] and Department of Pediatrics and the Child Development and Mental Retardation Center, University of Washington School of Medicine [W.E. T., D. M. K.J Seattle, Washington, USA

\section{Summary}

The possible acute deleterious effects of maternal glucocorticoid administration on the fetal nervous system and the pathologic significance of sudanophilic lipids in glial cells were studied in the premature pigtail monkey (macaca mulatta). At 72,48 , and $24 \mathrm{~h}$ before delivery at $135 \pm 1 \mathrm{~d}$ gestation, dams were treated with either $4 \mathrm{mg}$ dexamethasone or saline. After delivery, respiratory function of each fetus was determined and supported. The animals were sacrificed at $3 \mathrm{~h}$ of age.

Brain weights were similar in the two groups. Dark, shrunken, pyknotic neurons were present in the hippocampus of three treated and two control animals. Lipid-containing glial cells were present in all animals. Neither appeared to be related to steroid treatment or to the degree of respiratory distress.

We conclude that short-term glucocorticoid therapy in doses 